Volume 3

\title{
Young Investigator Awards
}

Follow this and additional works at: https://jdc.jefferson.edu/bodinejournal

Part of the Oncology Commons

\section{Let us know how access to this document benefits you}

\section{Recommended Citation}

(2010) "Young Investigator Awards," Bodine Journal: Vol. 3 : Iss. 1 , Article 47.

Available at: https://jdc.jefferson.edu/bodinejournal/vol3/iss1/47

This Article is brought to you for free and open access by the Jefferson Digital Commons. The Jefferson Digital Commons is a service of Thomas Jefferson University's Center for Teaching and Learning (CTL). The Commons is a showcase for Jefferson books and journals, peer-reviewed scholarly publications, unique historical collections from the University archives, and teaching tools. The Jefferson Digital Commons allows researchers and interested readers anywhere in the world to learn about and keep up to date with Jefferson scholarship. This article has been accepted for inclusion in Bodine Journal by an authorized administrator of the Jefferson Digital Commons. For more information, please contact: JeffersonDigitalCommons@jefferson.edu. 


\section{Young Investigator Awards}

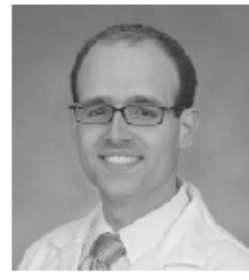

Robert Den, MD, is in his final year of residency training in the Department of Radiation Oncology and serves as one of our Chief Residents.

Dr. Den is the beneficiary of the Prostate Cancer Foundation Ben Franklin Young Investigator Award. He will investigate the role of retinoblastoma $(\mathrm{RB})$ modulation in radiation response under various clinically relevant conditions. This work could establish that $\mathrm{RB}$ status in prostate cancer cells is integral to determining which therapeutic modalities should be administered to patients with locally advanced prostate cancer.

In addition, Dr. Den was selected to attend two prestigious AACR/ ASCO (American Association of Cancer Research/American Society of Clinical Oncology) workshops. In July 2010, Dr. Den participated in the Molecular Biology in Clinical Oncology program, an intensive, one-week workshop on the latest developments in molecular biology relevant to clinical oncologists. In August, Dr. Den attended the Methods in Clinical Cancer Research, an intensive workshop in the essentials of effective clinical trial designs of therapeutic interventions in the treatment of cancer. Dr. Den's trial proposal examined the role of neoadjuvant radiation therapy combined with Vorinostat, a HDAC inhibitor, for the treatment of men with intermediate and high risk prostate cancer.

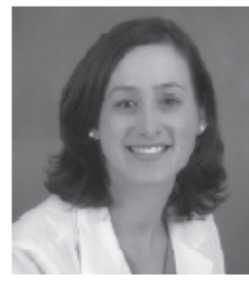

Laura Doyle, MS, came to Jefferson as a medical physicist in June, 2008 and is an outstanding asset to our team. In May, 2010, during the American Association of Physicists in Medicine's (AAPM) Spring Symposium, it was announced that Ms. Doyle was one of the recipients of this year's AAPM Travel Awards. The 2010 Meeting took place just blocks from the TJUH campus at the Philadelphia Convention Center and drew medical physicists from across the country. Thomas Jefferson University medical physicists had a strong presence at the meeting presenting promising new research, collaborating with others to form guidelines, and striving to achieve the highest in quality assurance and patient safety.

During this past year, Ms. Doyle was appointed as a member of the Task Group of the Use of Radiation Therapy for the Treatment of
Wet Macular Degeneration. This task group is formed under the American Society for Therapeutic Radiation Oncology (ASTRO) Emerging Technologies Evaluation Committee. Past reports have described advances in Radiation Oncology such as Stereotactic Body Radiotherapy and Electronic Brachytherapy.

Ms. Doyle was a critical member of Jefferson's Department of Radiation Oncology group which teamed up with the Retina Service at the Wills Eye Institute to participate in the CABERNET trial (CNV Secondary to a MD Treated with Beta Radiation Epiretinal Therapy) evaluating the use of brachytherapy for the treatment of wet age-related macular degeneration. This novel form of therapy involves placing a radioactive source just millimeters above the retinal bed to deliver therapeutic doses of radiation while sparing adjacent critical structures. The report from the ASTRO task group, still in preparation, will offer insight into the new technologies available in Radiation Therapy for the treatment of this common and vision-altering disease.

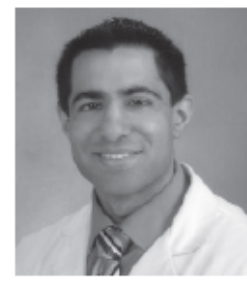

Nitin Ohri, MD, is a third year Resident in the Department of Radiation Oncology. In addition to performing his clinical duties and furthering his education, Dr. Ohri has initiated several promising research projects. His main interest is the use of functional imaging techniques in radiotherapy treatment planning and in the assessment of treatment response. He is already receiving recognition for his work.

Dr. Ohri was invited to attend the American Roentgen Ray Society (ARRS) Introduction to Academic Radiology Program that took place in San Diego this past May. This semi-annual workshop provides guidance for young physicians pursuing a career in academic medicine. His invitation included registration to the concurrent Radiological Society of North America (RSNA) annual meeting as well as a travel stipend.

Dr. Ohri also received an RSNA Research Resident Grant for his proposal "Spatial Response Patterns of Locally Advanced Non-small Cell Lung Cancer After Chemoradiation: A Secondary Analysis of ACRIN 6668 / RTOG 0235". He will perform this study, among others, during his research year.

Continued next page 


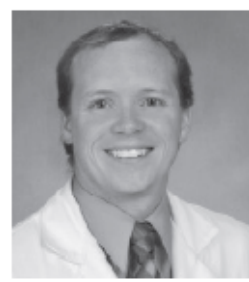

Evan Wuthrick, MD, is one of the Chief Residents in the Department of Radiation Oncology. He will finish his training here at Jefferson on June 30, 2011.

Dr. Wuthrick was selected to participate in two workshops sponsored by the American Association of Cancer Research/ American Society of Clinical Oncology. In July 2010 he attended the Molecular Biology in Clinical Oncology workshop held at the Given Institute of the University of Colorado in Aspen. It was an intensive, week-long educational opportunity on the latest developments in molecular biology relevant to clinical oncologists. New research on the molecular mechanisms that control cell growth has led to a rapid expansion in the understanding of the nature of cancer cells which has opened many potential avenues of translational cancer research. The goal will be to provide a thorough overview of the emerging role of molecular biology in clinical cancer care.
In August 2010 Dr. Wuthrick attended the American Society of Clinical Oncology/American Association of Cancer Researchers sponsored workshop entitled Methods in Clinical Cancer Research. The workshop was held in Vail, Colorado and focused on the design and conduct of clinical trials. Clinical trials completed in oncology provide definitive answers about the effectiveness of new approaches to cancer treatment or prevention. As part of the application for this workshop, Dr. Wuthrick submitted a detailed clinical trial proposal entitled, "Pilot Study to Reduce the Severity of Gastrointestinal Toxicity Using Concurrent Linaclotide with Chemoradiotherapy in Pancreatic Adenocarcinoma." The concept for this proposed clinical trial stems from work done in the laboratory of Dr. Scott Waldman, Professor and Chair of the Department of Pharmacology and Experimental Therapeutics at Jefferson.

\section{Research \\ Department of Radiation Oncology}

\section{Basic Research Studies/Grants}

- 17AAG abrogates repair of DSBs by HR in tumor cells at acidic $\mathrm{pH}$ but not at $\mathrm{pH} 7.3$

- Spatial Response of Locally Advanced Non-Small Cell Lung Tumors to Radiotherapy: A Secondary Analysis of ACRIN 6668 / RTOG 0235

- Prostate Cancer Foundation Young Investigator Awards

- RTOG Group Member Agreement

- Physicist Chair

- Vice Chair Translational Research Program

\section{Clinical Research Studies/Grants}

- RTOG \#0848 : A Phase III Trial Evaluating Both Erlotinib and Chemoradiation as Adjuvant Treatment for Patients with Resected Head of Pancreas Adenocarcinoma

- RTOG \#0815 : A Phase III Prospective Randomized Trial of Dose-Escalated Radiotherapy with or without Short-Term Androgen Deprivation Therapy for Patients with IntermediateRisk Prostate Cancer

- NIH: Phase I Study: Using EUCLIDIAN Robotic Assistance During Prostate Brachytherapy (NIH/NCI CA091763: CA107860)
- RTOG \#0831/Cialis: A randomized, double-blinded, placebocontrolled phase III trial to evaluate the effectiveness of a phosphodiesterase 5 inhibitor, tadalafil, in prevention of erectile dysfunction in patients treated with radiotherapy for prostate cancer

- Wyeth/Pfizer : A Pilot Study of Chemoradiotherapy Plus Temsirolimus (Torisel) for Advanced Head and Neck Cancer

- RTOG\#0631: Phase II/III Study of Image-Guided Radiosurgery/ SBRT for Localized Spine Metastasis

- RTOG \#0627: Phase II Trial of Dasatinib in Patients with Recurrent Glioblastoma Multiforme

- NCCTG \#N0577: Phase III Intergroup Study of Radiotherapy versus Temozolomide alone versus Radiotherapy with Concomitant and Adjuvant Temozolomide for Patients with 1p/19q Codeleted Anaplastic Glioma

- RTOG \#0539: Phase II Trial of Observation for Low-Risk Meningiomas and of Radiotherapy for Intermediate- and HighRisk Meningiomas

- ECOG E3F05: Phase III Study of Radiation Therapy with or without Temozolomide for Symptomatic or Progressive Low-Grade Gliomas 